\title{
Modeling the Impact of Mine and Country Variations on the Cost and Country-Benefit of Gold Mining
}

\author{
Karim Baruti, Antipas T. S. Massawe, Beatus Alois Kundi \\ College of Engineering and Technology, University of Dar es Salaam, Dar es Salaam, Tanzania \\ E-mail: karimbaruti@udsm.ac.tz \\ Received November 23, 2010; revised January 11, 2011; accepted January 18, 2011
}

\begin{abstract}
This paper dwells on regression models of cash-cost and country-benefit developed to enable accounting for the cumulative impact of the determinant parameters in the prediction of cash-costs and country-benefits of gold mining opportunities in the justification of taxation regimes and selection of investment targets worldwide. The data used in the generation of regression models include the total cash-cost and country-benefit per ounce vs the parameters of rock-mass (type of ore body, its dip angle, strike length and thickness), mine-design (rate of gold production, type of mine, depth of mine, gold price and age of mine) and country parameters (the Fraser Institute parameters: taxation regime, infrastructure, environmental regime, political stability, labor regulations and security) were generated from 160 gold mines in the top 20 gold rich countries for a period of 7 years from 2002 to 2008. The regression models show that the determinants account for $71 \%$ and $55 \%$ of the determinants of cash-cost and country-benefit respectively. Depending on the availability of data, the regression models generated in this study could be enhanced by adding into the parameters used in the regression analysis, the unaccounted for mine and country parameters. Also, Depending on the availability of data, the Regression models generated in this study could be enhanced further by replacing the parameters of Fraser Institute ranking used in the regression analysis with the actual parameters of country effect on cash-cost and country-benefit of the gold produced. Nevertheless, the regression models generated in this study could be used to predict the cash-costs and country-benefits of gold mining opportunities in the justification of taxation regimes and selection of investment targets worldwide.
\end{abstract}

Keywords: Rock-Mass Parameters, Mine-Design Parameters, Country Parameters, Regression Models

\section{Introduction}

Cash-cost and country-benefit per ounce of the gold produced from any mine in any country are determined by the parameters of rock-mass, mine-design and the country where a gold mine operates. While gold rich countries competing for mining investment tend to go for the taxation regimes maximizing country-benefits and their attractiveness for mining investment, investors looking for gold mines to develop tend to go for the gold mining opportunities of least cash-cost in production. Therefore, to be effective, a gold mine should deliver the maximum possible benefit to the country where the mine operates and cash-cost which is comparable to the cash-costs of production in the other gold mines worldwide. Consequently, the desired effectiveness of a gold mine could be achieved from the taxation regime delivering the maximum country-benefit and cash-cost which is comparable to cash-costs in the other gold mines worldwide. The most effective taxation regime for a gold mine could be established based on the mathematical models of the cumulative impact of the determinant rock-mass, mine design and country variations on the cash-cost and country-benefit of gold mining worldwide. The country parameters and experts' view-based model of different countries ranking in accordance to their attractiveness for mining investment developed by the prestigious Canadian Fraser Institute is the only main one used by gold rich countries in the formulation of taxation regimes and mining investors in the selection of investment targets. However, using the Fraser Institute model alone is difficult to assess and compare the cumulative impact of rock-mass, mine-design and country variations of competing gold mining opportunities on the cash-cost and country-benefit of gold production in the formulation of taxation regimes and selection of gold 
mining targets worldwide. Even though, the determinant parameters of country attractiveness for gold mining investment considered and their values generated by the Fraser Institute for different gold rich countries could be incorporated with the rock-mass, mine-design, country-benefit and cash-cost variations of gold mining worldwide to enable development of the required mathematical models as regressions of the cumulative influence of determinant parameters on the cash-cost and country-benefit of gold mining worldwide. Therefore, the objective in this paper is to develop the regressions models of cash-cost and country-benefit fit on the rock-mass, mine-design and country variations of gold mining based on the unit cost and country-benefit vs the parameters of rock-mass and mine-design variations of gold mining and the Fraser Institute-developed parameters of country attractiveness for gold mining and their values for different countries worldwide.

\section{Assessment of Gold Mining Effectiveness}

\subsection{Existing Models}

\subsubsection{Standard Gold Model Based ETR and IRR Indices}

These indices have been described in detail by Otto [1]. Effective Tax Rate (ETR) and Internal Rate of Return (IRR) are used to explain country-benefit and profitability of gold mines. ETR is a measure, expressed as a percentage of the effective net cash-flow, of all amounts payable by the company to the government. It compares the government fiscal take of the project and can be used by investors and government to compare the taxation system of a country using standard gold model established by the Institute for Global Resources Policy and Management (IGRPM) and Colorado School of Mines or any other mine model, calculated by summing the present value of all taxes and other payments to the government paid in each year, then dividing the sum by present value of the total effective annual cash-flow. Although the standard gold model based ETR is a very strong criterion for assessing a variety of taxation systems of different countries, it generates ETR in relative and not in absolute terms. IRR is defined as that interest rate which equates the sum of the present value of inflows with the sum of the present value of cash-outflows for a project or alternatively IRR is the interest rate at which the net present value of a project is equal to zero. While the IRR is a useful index for determining the effect of a fiscal system on profitability, it does not provide gold rich countries with a measure of their fiscal take. However, by looking at both before - tax and after tax IRRs, an investor can compare how the various methods of taxation have an impact on IRR of the project.

The Standard gold model based ETR and IRR indices can be used together to compare the taxation system of a country. For example, studying taxation in various countries Otto used this standard gold model to generate ETR and IRR ranks for various gold mining countries. The country which received lowest ETR rank was Sweden $(29 \%)$ and the country which received the highest rank was Burkina Faso (81\%). The opposite was true for IRR in which Sweden ranked (18.8\%).

The main disadvantage of the standard gold model based ETR and IRR indices is that they dwell on taxation alone and using them does not allow predicting the impact of rock-mass, mine-design and country variations on cash-cost and country benefit in the comparison of gold mining opportunities in the formulation of taxation regimes or selection of investment targets.

\subsubsection{Fraser Institute Models}

Fraser Institute models dwell on ranking the countries which are considered to host major explorations and mining projects based on conducted annual surveys of metal mining and exploration companies to collect their assessments on how mineral endowments and public policy factors such as taxation and regulations affect exploration investment. For example, the surveys of 2008/09 considered and ranked 72 jurisdictions around the world based on 14 criteria [2]. Quebec was ranked first, meaning that its policy potential is the most attractive for mining investment while Venezuela was the last in the ranking, meaning that its public policy is the least attractive for mining investment. Since 1997, Fraser Institute has been publishing results of its annual surveys.

Ranks of countries attractiveness based on Fraser Institute models are the main guides in the formulation of taxation regimes and selection of investment targets in the gold mining industry worldwide. One of disadvantages in the Fraser Institute models is that they only dwell on public policies and mineral potentials effects on mining investments. Another disadvantage of these models is that generation of rankings for different countries attractiveness for mining investment is only based on qualitative and perceptions of respondents in the survey. Also, same as the standard gold model based ETR and IRR, the Fraser Institute models do not enable prediction of the impact of rock-mass, mine-design and country variations of gold mining opportunities worldwide on cash-cost and country benefit in the formulation of taxation regimes and selection of investment targets.

However, the 14 ranking criteria of country attractiveness for gold mining investment and their values for different countries generated annually by Fraser Insti- 
tute have been incorporated with the rock-mass and mine-design variations of gold mining in the countries examined in this study in the regression analysis and generation of the regression models of cash-cost and country-benefit fit on the determinant rock-mass, mine design and country variations of gold mining worldwide.

\subsection{Mathematical Models Development}

\subsubsection{Description of Cash-Cost and Country-Benefit}

Cash-cost and country-benefit measured in US\$/oz are the two main indices of effectiveness in gold mining. As recommended by the World Gold Institute, cash-cost includes all direct mining and processing expenses, other on-site charges, third-party smelting and refining charges as well as royalties and production taxes net of by-product credits. It does not include depreciation, depletion and amortization, reclamation and closure costs. General and administrative expenses as well as exploration expenses at corporate level are also not included [3-4]. Since cash-cost is the main component of total cost, it has been used as a proxy for total cost in absence of the other components. Country-benefit is the benefit of any gold mining investment to the government of the country where it is operating. It includes many components but the country-benefit assessed in this study only includes the components of royalties and production taxes measured in US dollar per ounce. Royalties are charged based on production volume, or assessed on the value of gold produced, or can be calculated on gross or net of costbasis. Whatever forms of royalties, they are attractive to the government because they ensure an up-front revenue stream as soon as production starts [5]. Production taxes include import duties; value-added-tax (VAT) and any indirect taxes. Many studies, including [6-7] have shown that it is the royalties and production taxes imposed at a too high rate rather than income taxes (which are more or less neutral to investor decision) constitute a major deterrent to investment. The available actual cash-costs of the operating gold mines worldwide have been used in the formulation of taxation regimes and selection of investment targets [8]. Therefore, the available data on royalties and all indirect taxes related to gold mining worldwide has been used as the measure of country-benefits in this study. Most of the time investors or mine operators tend to minimize cash-cost in order to increase profit-margins or company-benefits while the countries where mining is taking place tend to maximize royalties and/taxes in order to increase country-benefit. However, the actual cash-cost and country-benefit comparison of different gold mining opportunities in the formulation of taxation regimes and selection of investment targets is only based on the direct utilization of the actual cash-cost and country-benefits realized from different mines and therefore does not allow to account for the impact of rock-mass, mine design and country variations of gold mining opportunities in the comparison of their cash-costs and country-benefits effects in the formulation of taxation regimes and selection of investment targets. It is the mathematical models of the impact of rock-mass, mine design and country variations on the cash-cost and country-benefit variations of gold mining worldwide are required for the comparison of gold mining opportunities in the formulation of taxation regimes and selection of investment targets.

\subsubsection{Determinants of Cash-Cost and Country-Benefit}

Cash-cost and country-benefit effects of any gold mine are determined by several country and mine parameters. Country parameters include those which deter and those which encourage investment and mine parameters include rock-mass and mine-design parameters of a gold mine, main of which are shown in Table $\mathbf{1}$.

The determinant parameters of rock-mass and mine -design presented on Table 1 were established from literature review [9-15]. Different lists of determinant country parameters have been established by different authors [16-19], but the list generated by the Fraser Institute is the one considered in this study because it covers most of the important country characteristics which affect the cash-cost and country-benefit of gold mining from any mine. In addition, most of the countries included in the Fraser annual surveys are also in the list of countries examined in this study and therefore their data could be easily obtained from these surveys. While mine variables are unregulated, some of the determinant coun-try parameters could be regulated to deliver the maximum country-benefit and at a cash-cost which is still within the range of costs attracting investment in the mining industry.

\subsection{Regression Models of Cash-Cost and Country-Benefit}

\subsubsection{Formulation}

Aim of this study is to develop regression models of cash-cost and country-benefit fit on the main determinant rock-mass, mine-design and country parameters, some of which could be regulated to obtain the desired levels of effect in cash-cost and country-benefit. General formulations of the regression models of cash-cost and the country-benefit are as shown in formulas (1) and (2).

$$
\begin{gathered}
C_{t}=F_{C_{t}}\left(a_{i}, b_{j}, X_{k l}\right) \\
B_{t}=F_{B_{t}}\left(a_{i}, b_{j}, X_{k l}\right)
\end{gathered}
$$


Table 1. Parameters affecting cash-cost and country-benefit.

\begin{tabular}{|c|c|}
\hline $\begin{array}{c}\text { Category of } \\
\text { Determinants }\end{array}$ & Content of Parameters \\
\hline \multirow{4}{*}{ 1. Country } & Those deterring investment: \\
\hline & $\begin{array}{l}\text { 1.1 Uncertainty concerning the administration, interpretation and enforcement of existing regulations; } 1.2 \text { Environmental } \\
\text { regulations; } 1.3 \text { Regulatory duplication and inconsistencies (including federal/provincial or federal/state and interdepart- } \\
\text { mental overlap); } 1.4 \text { Taxation regime (including personal, corporate, payroll, capital taxes and the complexity associated } \\
\text { with tax compliance); } 1.5 \text { Uncertainty concerning native land claims; } 1.6 \text { Uncertainty concerning which areas will be } \\
\text { protected as wilderness or parks, } 1.7 \text { Infrastructure; } 1.8 \text { Socioeconomic agreements; } 1.9 \text { Political stability; } 1.10 \text { Labor } \\
\text { regulations/ employment agreements; } 1.11 \text { Geological database (including quality and scale of map and ease of access to } \\
\text { information); } 1.12 \text { Security. }\end{array}$ \\
\hline & Those encouraging investment: \\
\hline & $\begin{array}{l}\text { 1.13 Mineral potential assuming current regulations and land use restriction; } 1.14 \text { Current mineral potential assuming } \\
\text { current regulations/ Land use restrictions and } 1.15 \text { Policy/mineral potential assuming no land use restrictions in place and } \\
\text { assuming industry best practices. }\end{array}$ \\
\hline \multirow{4}{*}{ 2. Mine } & Rock-mass: \\
\hline & $\begin{array}{l}2.1 \text { Resource size }(\mathrm{Mt}) ; 2.2 \text { resource grade }(\mathrm{g} / \mathrm{t}) ; 2.3 \text { quantity of resource gold }(\mathrm{t}) ; 2.4 \text { Reserve size }(\mathrm{Mt}) ; 2.5 \text { reserve } \\
\text { grade }(\mathrm{t}) ; 2.6 \text { quantity of reserve gold }(\mathrm{t}) ; 2.7 \text { run of mine size }(\mathrm{Mt}) ; 2.8 \text { run-of-mine grade }(\mathrm{g} / \mathrm{t}) ; 2.9 \text { quantity } \\
\text { run-of-mine gold }(\mathrm{t}) ; 2.10 \text { type of ore body; } 2.11 \text { dip angle (degree);2.12 strike length }(\mathrm{m}) ; \text { and } 2.13 \text { thickness }(\mathrm{m}) ; 2.14 \\
\text { hardness of host rock* }\end{array}$ \\
\hline & Mine Design: \\
\hline & $\begin{array}{l}2.14 \text { Rate of gold production (t/yr); } 2.15 \text { type of mine; } 2.16 \text { depth of mine }(\mathrm{m}) ; 2.17 \text { age of mine (years); } 2.18 \\
\text { by-product; } 2.19 \text { Gold price (US US\$/oz). }\end{array}$ \\
\hline
\end{tabular}

Source: Derived by authors from different sources. Note: units are presented in brackets, country variables are measured in percentage and hardness are measured in a scale of 1,2 and 3 indicating relative hard, hard and very hard host rock respectively.

Where: $a_{i}-$ the $i^{\text {th }}$ rock-mass parameter; $b_{j}-$ the $\mathrm{j}^{\text {th }}$ mine design parameter; $X_{k l}-$ the $l^{\text {th }}$ value of $k^{\text {th }}$ country parameter.

\subsubsection{Data Base}

The first top 20 gold producing countries based on GFMS surveys of 2005 were selected as gold rich countries and their active gold mines were selected based on a number of established criteria. However, Zimbabwe, Philippines and Colombia were removed from the list for different reasons including political instability in Zimbabwe, most of the gold produced in Philippines been a by-product, and limited information which could be compiled on Columbia. These countries were replaced by Guinea and Burkina Faso in order to increase the number of developing countries in the study. Consequently, 19 countries were included in the study and reviewed from 2002 to 2008 because data for these countries for the period was available. The established criteria include, first: availability of data, second; status of the mine, i.e. whether the mine is operating, closed, suspended or is under special care. The operating mines were selected in preference of the others. Third, types of gold deposits, i.e. whether a gold deposit is primary, alluvial, or tailings. The primary deposit gold mines were selected because the nature of operations fits most of gold mines in many countries and constitutes a comprehensive cash-cost. The fourth criterion was whether gold is produced as the main or by-product. Those mines where gold is produced as the main product were selected. As a result, 160 gold mines were selected representing $21 \%$ of gold mines in these countries. The main sources of data are as shown in Appendix 1.

\subsubsection{Regression Analysis}

For each variable, analysis was carried out to assess the assumption of normality of the data in addition to other assumptions such as homogeneity of variance, interval and independence of data, respectively. The non-normal data for variables such as resource-size, resource-grade, quantity of resource-gold, reserve-size, reserve-grade, quantity of reserve-gold, run-of-mine size, run-of-mine grade, and quantity of run-of-mine gold were normalized by transforming them into a common logarithm. Data for variables such as type of ore-body, type of mine, dip angle, strike length, thickness of ore body, depth of mine and age of mine were converted into categorical variables and their dummy variables were established. Scatter plots of the two indices cash-cost and country-benefit vis- a - vis each continuous independent variables were established and they revealed a linear relationship of each index and each of these variables.

The regression analysis was carried out using the Mul- 
tiple-Linear-Regression Analysis SPSS standard software because several variables determine cash-cost and country-benefit. The determinant variables were divided into two blocks of independent variables in which mine variables and country variables were in the first and second blocks respectively. Purpose was first; to explore separately the relationship between cash-cost fit on mine variables, second; cash-cost fit on country variables, third; cash-cost fit on mine and country variables, and fourth; country-benefit fit on mine variables, fifth; country-benefit fit on country variables and sixth; country-benefit fit on mine and country variables. The regression models generated are as summarized in Table 2.

\subsubsection{Discussion of Regression Analysis}

The lists of significant and insignificant determinant parameters of cash-cost are shown on Appendix 2.

\section{$>$ Significant Determinants of Cash-Cost}

Beginning with the most significant, the 13 significant parameters of cash-cost are: gold price; the rate of gold production; the run-of-mine grade; rock hardness; ore- body thickness; presence of by-products; type of mine; regulatory duplications; environmental regulations; type of ore-bodies; strike length; depth of mine and age of mine.

$>$ Insignificant determinants of cash-cost

The insignificant parameters of cash-cost are 4: taxation regime; labor regulations; political stability and dip-an-gle of ore-body.

$>$ Significant determinants of country-benefit

Beginning with the most significant, the 10 significant parameters of country-benefit are: the infrastructure; age of mine; gold price; thickness of ore; type of ore; strike- length; taxation regime; uncertainty concerning native land claims; rate of gold production and dip-angle.

$>$ Insignificant determinants of country benefit

The insignificant parameters of country-benefit are 6: therun-of-mine grade; labor regulations; socioeconomic agreement; type of mine; presence of by-products and hardness of host rock.

\subsubsection{Regression Models Generated}

The estimated regression models of cash-cost fit on the mine and country variables separately $\left(C_{c} \frac{U S \$}{O Z}\right.$ and $\left.C_{m} \frac{U S \$}{O Z}\right)$, and combined $\left(C_{m} \frac{U S \$}{O Z}\right)$ are as shown on Formula 3, 4 and 5 respectively:

$$
\begin{aligned}
C_{\mathrm{m}}= & 144.27-65.11 \log a_{8}+31.72 b_{15 \mathrm{C}_{\mathrm{m}}} \\
& -34.61 a_{12 C \mathrm{~m}}+a_{\mathrm{m}}+a_{14 C_{m}}-57.55 \log b_{14} \\
& +31.71 a_{11 C_{m}}+b_{16 C_{m}}+b_{17 \mathrm{C}_{\mathrm{m}}}-29.73 b_{18} \\
& +52.56 a_{10 \mathrm{C}_{\mathrm{m}}}+0.49 \mathrm{~b}_{19} \\
C_{\mathrm{c}}= & 165.74+176.92 X_{6}+131.70 X_{4}+203.03 X_{7} \\
+ & 329.09 X_{10}+17.51 X_{13}-167.57 X_{9}-201.75 X_{12} \\
C_{\mathrm{cm}}= & 152.41-59.66 \log a_{8}+54.27 a_{10 \mathrm{C}_{\mathrm{mc}}} \\
& -34.83 a_{12 C m c}+a_{13 \mathrm{C}_{\mathrm{mc}}}+a_{14}-59.55 \log b_{14} \\
+ & 34.71 b_{15}+b_{16 C_{m c}}+b_{17 \mathrm{C}_{\mathrm{mc}}}-26.20 b_{18}+0.49 \mathrm{~b}_{19} \\
+ & 54.14 X_{2}+79.91 X_{3}
\end{aligned}
$$

Similarly, the estimated regression models of country-benefit fit on mine and country variables separately ( $B_{c} \frac{U S \$}{O Z}$ and $B_{m} \frac{U S \$}{o z}$, and combined $\left(B_{c m} \frac{U S \$}{o z}\right.$ ) are as shown on Formula 6,7 and 8 respectively:

$$
\begin{aligned}
B_{\mathrm{m}}= & 46.46+9.04 a_{10 \mathrm{~B}_{\mathrm{m}}}+a_{11}+11.42 a_{12 \mathrm{~B}_{m}} \\
& -23.93 a_{13 \mathrm{~B}_{\mathrm{m}}}-6.62 a_{14 \mathrm{~B}_{m}}-14.34 \log b_{14} \\
& +b_{15 \mathrm{~B}_{\mathrm{m}}}+b_{16 \mathrm{~B}_{\mathrm{m}}}+\mathrm{b}_{17 \mathrm{~B}_{\mathrm{m}}}+0.03 \mathrm{~b}_{19}-6.91 b_{18} \\
B_{c}= & 34.32 X_{4}+35.96 X_{7}-35.40 X_{12} \\
B_{m c}= & 34.41+12.37 a_{10 \mathrm{~B}_{\mathrm{mc}}}-9.64 a_{11}+a_{12 \mathrm{~B}_{m c}}+a_{13 \mathrm{~B}_{\mathrm{mc}}} \\
- & 11.54 \log b_{14}+14.86 b_{16 \mathrm{~B}_{\mathrm{mc}}}+\mathrm{b}_{17 \mathrm{~B}_{\mathrm{mc}}} \\
+ & 0.03 \mathrm{~b}_{19}+25.09 X_{4}-16.85 X_{5}+39.28 X_{7}
\end{aligned}
$$

Where: $a_{8}$ - the run-of-mine grade of gold $(\mathrm{g} / \mathrm{t})$; $a_{10 \mathrm{C}_{\mathrm{m}}}$ and $a_{10 \mathrm{~B}_{\mathrm{m}}}$ - Type of ore-body effects on cost and benefit; $a_{11}$-dip angle of ore-body $\left({ }^{0}\right) ; a_{12 C_{m}}$ and $a_{12 B_{m}}-$ ore-body strike-length effects on cost and benefit; $a_{13 C_{\mathrm{m}}}$

Table 2. Regression models summary.

\begin{tabular}{lccccccc}
\hline \multicolumn{1}{c}{ Model } & R & R square & $\begin{array}{c}\text { Adjusted R } \\
\text { square }\end{array}$ & F change & df1 & df2 & $\begin{array}{c}\text { Sig. F } \\
\text { change }\end{array}$ \\
\hline 1. Cash-cost vs mine variables & 0.835 & 0.697 & 0.681 & 44.431 & 35 & 676 & .000 \\
2. Cash-cost vs country variables & 0.584 & 0.341 & 0.323 & 19.083 & 14 & 516 & .000 \\
3. Cash-cost vs mine and country variables & 0.840 & 0.705 & 0.686 & 37.941 & 40 & 635 & .000 \\
4. Country benefit vs mine variables & 0.711 & 0.506 & 0.437 & 7.347 & 35 & 251 & .000 \\
5. Country benefit vs country variables & 0.527 & 0.277 & 0.230 & 5.866 & 14 & 214 & .000 \\
6. Country benefit vs mine and country variables & 0.742 & 0.55 & 0.473 & 7.097 & 40 & 232 & .000 \\
\hline
\end{tabular}


and $a_{13 \mathrm{~B}_{\mathrm{m}}}$ - Category of ore-body thickness effects on cost and benefit; $a_{14}-$ hardness of host rock; $b_{14}-$ the rate of gold production from a mine ( $\mathrm{t} / \mathrm{yr}$ ); $b_{15 \mathrm{C}_{\mathrm{m}}}$ and $b_{15 \mathrm{~B}_{\mathrm{m}}}$ - type of mine effects on cost and benefit; $b_{16 C_{m}}$ and $b_{16 B_{m}}$ - mine depth (m) effects on cost and benefit; $b_{17 \mathrm{C}_{\mathrm{m}}}$ and $b_{17 \mathrm{~B}_{\mathrm{m}}}$ - age of mine (years) effects on cost and benefit; $b_{18}-$ presence of by-product/s; $b_{19}$ - the annual average price of gold (US\$/ oz); $X_{2}$ - environmental regulations; $X_{3}$ - regulatory duplication and inconsistencies; $X_{4}$ - taxation regime deterrence of investment $(\%) ; X_{5}-$ Uncertainty concerning native land claims deterrence of investment (\%) $X_{7}$ - Infrastructural deterrence of investment $(\%) ; X_{6}$ - Uncertainty concerning which areas will be protected as wilderness or parks; $X_{9}-$ Political stability deterrence of investment; $X_{10}$ - Labor regulations/ employment agreements deterrence of investment; $X_{11}$ - Geological database (including quality and scale of map and ease of access to information) deterrence of investment; $X_{12}$ - Security deterrence of investment; $X_{15}-$ Policy/mineral potential assuming no land-use restrictions are in place and assuming industry best practices encouraging investment

$$
\begin{aligned}
& b_{15 C_{m}}= \begin{cases}0, & \text { for } O P \text { or } U G . \\
1, & \text { for } O P \text { and } U G .\end{cases} \\
& b_{15 B_{m}}=\left\{\begin{array}{c}
0, \text { for } O P \\
-12.80, \text { for } U G \\
-9.27, \text { for } O P \text { and } U G
\end{array} ;\right. \\
& b_{18}=\left\{\begin{array}{l}
0, \mid \text { without byproduct } \\
1, \mid \text { with byproduct. }
\end{array} ;\right.
\end{aligned}
$$

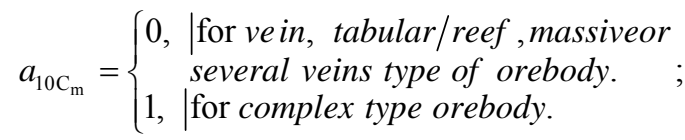

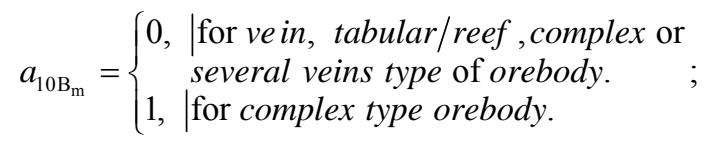

$$
\begin{aligned}
& a_{11 C_{m}}=\left\{\begin{array}{c}
0, \mid \text { for } 20^{\circ} \leq \text { dip angle } \geq 90^{\circ} \\
1, \mid \text { for } 0^{\circ}<\text { dip angle } \leq 20^{\circ}
\end{array} ;\right. \\
& a_{11 B_{m}}=\left\{\begin{array}{c}
0, \text { for } 60^{\circ}<\text { dip angle } \leq 90^{\circ} \\
-16.33, \text { for } 0^{\circ}<\text { dip angle } \leq 20^{\circ} \\
-11.88, \text { for } 20^{\circ}<\text { dip angle } \leq 40^{\circ}
\end{array}\right. \\
& a_{12 B_{m}}=\left\{\begin{array}{c}
0, \mid \text { for } 500<\text { strike length } \leq 1500 \mathrm{~m} \\
\text { or strike length }>2000 \mathrm{~m} . \\
1, \quad \text { for } 1500 \mathrm{~m}<\text { strike length } \leq 2000 \mathrm{~m}
\end{array} ;\right.
\end{aligned}
$$

$a_{13 \mathrm{C}_{\mathrm{m}}}=\left\{\begin{array}{c}0, \text { for thickness }<2.0 \mathrm{~m} \text { or complex. } \\ -35.04, \text { for } 2.0 \mathrm{~m}<\text { thickness } \leq 5.0 \mathrm{~m} . \\ -45.81, \text { for } 5.0 \mathrm{~m}<\text { thickness } \leq 10.0 \mathrm{~m} . \\ -28.94, \text { for thickness }>10.0 \mathrm{~m} .\end{array} ;\right.$

$a_{13 \mathrm{~B}_{\mathrm{m}}}=\left\{\begin{array}{c}0, \text { for } 0 \leq \text { thickness } \geq 10 \mathrm{~m} \\ 1, \text { forcomplex }\end{array}\right.$;

$a_{14 C_{m}}=\left\{\begin{array}{l|l}-28.73, & \text { for relative hard rock. } \\ -58.84, & \text { for hard and very hard rock. }\end{array}\right.$;

$a_{14 B_{m}}=\left\{\begin{array}{l}0, \mid \text { for relative hard rock and very hard rock. } \\ 1, \mid \text { for hard rock. }\end{array}\right.$

$b_{16 C_{m}}=\left\{\begin{array}{c}0, \mid \text { for depth }<300 \mathrm{~m} \\ \text { or } 300 \mathrm{~m}<\text { depth } \leq 1000 \mathrm{~m} \\ \text { 0r } 1500<\text { depth } \leq 2000 \mathrm{~m} \\ 39.27, \mid \text { for } 1000 \mathrm{~m}<\text { depth } \leq 1500 \mathrm{~m} \\ 40.91, \mid \text { for } 2000 \mathrm{~m}<\text { depth } \leq 3000 \mathrm{~m}\end{array}\right.$

$b_{16 B_{m}}=\left\{\begin{array}{c}0, \text { for } 0 \leq \text { depth } \leq 500 \mathrm{~m} \\ 14.91, \text { for } 500 \mathrm{~m}<\text { depth } \leq 1000 \mathrm{~m} \\ -18.21, \text { for } 1500 \mathrm{~m}<\text { depth } \leq 2000 \mathrm{~m} \\ -21.38, \text { for } 2000 \mathrm{~m}<\text { depth } \leq 3000 \mathrm{~m}\end{array}\right.$

$b_{17 \mathrm{C}_{\mathrm{m}}}=\left\{\begin{array}{c}0, \quad \text { for age }>30 \text { years or } \\ 11 \text { years } \leq \text { age } \leq 15 \text { years or age } \leq 5 \text { years } \\ 27.41, \text { for } 21 \text { years } \leq 25 \text { years. } \\ 31.05, \text { for } 26 \text { years } \leq \text { age } \leq 30 \text { years. }\end{array} ;\right.$

$b_{17 \mathrm{~B}_{\mathrm{m}}}=\left\{\begin{array}{c}0, \text { for age }>30 \text { years or } 26 \text { years } \leq \text { age } \leq 30 \text { years } \\ \text { or } 6 \text { years } \leq \text { age } \leq 10 \text { years or } 0<\text { age } \leq 5 \text { years. } \\ -13.65, \text { for } 21 \text { years } \leq \text { age } \leq 25 \text { years } . \\ -18.41 \text {, for } 16 \leq \text { age } \leq 20 \text { years. } \\ -12.42, \text { for } 11 \text { years } \leq \text { age } \leq 15 \text { years. }\end{array} ;\right.$

$b_{15}=\left\{\begin{array}{l}0, \mid \text { for } O P \text { or } U G . \\ 1, \mid \text { for } O P \text { and } U G .\end{array} ;\right.$

$a_{13 \mathrm{C}_{\mathrm{m}}}=\left\{\begin{array}{ll}0, & \text { for vein, tabular/reef }, \text { massive or } \\
\text { several vein stype of orebody } & \text { |for complex type orebody }\end{array} ;\right.$

$a_{13 \mathrm{~B}_{\mathrm{m}}}=\left\{\begin{array}{ll}0, & \begin{array}{l}\text { for vein }, \text { tabular/reef }, \text { complex or } \\
\text { several vein stype of orebody }\end{array} \\
1, & \text { for massive type of orebody }\end{array} ;\right.$

$a_{12 \mathrm{Cm}}=\left\{\begin{array}{c}0, \quad \text { for strike length } \leq 1500 \mathrm{~m} \\ \quad \text { or strike length }>2000 \mathrm{~m} . \\ 1, \quad \text { for } 1500 \mathrm{~m}<\text { strike length } \leq 2000 \mathrm{~m} .\end{array} ;\right.$

$a_{12 B_{m}}=\left\{\begin{array}{c}0, \quad \begin{array}{l}\text { for } 500<\text { strike length } \leq 1500 \mathrm{~m} \\ \text { or strike length }>2000 \mathrm{~m} .\end{array} \\ 1, \quad \text { for } 1500 \mathrm{~m}<\text { strike length } \leq 2000 \mathrm{~m} .\end{array}\right.$; 


$$
a_{13 \mathrm{C}_{\mathrm{m}}}=\left\{\begin{array}{c}
0, \text { for thickness }<2.0 \mathrm{~m} \text { or complex. } \\
-35.33, \text { for } 2.0 \mathrm{~m}<\text { thickness } \leq 5.0 \mathrm{~m} . \\
-43.12, \text { for } 5.0 \mathrm{~m}<\text { thickness } \leq 10.0 \mathrm{~m} . \\
-33.67, \text { for thickness }>10.0 \mathrm{~m} .
\end{array}\right.
$$

$a_{13 \mathrm{~B}_{\mathrm{m}}}=\left\{\begin{array}{c}0, \mid \text { for thickness } \leq 2.0 \mathrm{~m} \text { or }>10.0 \mathrm{~m} \text { or complex. } \\ 18.85, \text { for } 2.0 \mathrm{~m}<\text { thickness } \leq 5.0 \mathrm{~m} . \\ -21.14, \text { for } 5.0<\text { thickness } \leq 10.0 \mathrm{~m} .\end{array}\right.$;

$a_{14}=\left\{\begin{array}{l|l}-32.82, & \text { for relative hard rock. } \\ -70.42, & \text { for hard and very hard rock. }\end{array}\right.$;

$b_{16 C_{m}}=\left\{\begin{array}{c}0, \quad \text { for depth }<300 \mathrm{~m} \text { or } 300 \mathrm{~m}<\text { depth } \leq 1000 \mathrm{~m} \\ \text { or } 1500 \mathrm{~m}<\text { depth } \leq 3000 \mathrm{~m} . \\ 1, \quad \text { for } 1000 \mathrm{~m}<\text { depth } \leq 1500 \mathrm{~m} .\end{array} ;\right.$

$b_{16 B_{m}}=\left\{\begin{array}{l}0, \quad \text { for depth }<300 \mathrm{~m} \\ \text { or } 300 \mathrm{~m}<\text { depth } \leq 500 \mathrm{~m} \\ \text { or } 1000 \mathrm{~m}<\text { depth } \leq 3000 \mathrm{~m} . \\ 1, \quad \text { for } 500 \mathrm{~m}<\text { depth } \leq 1000 \mathrm{~m} .\end{array}\right.$

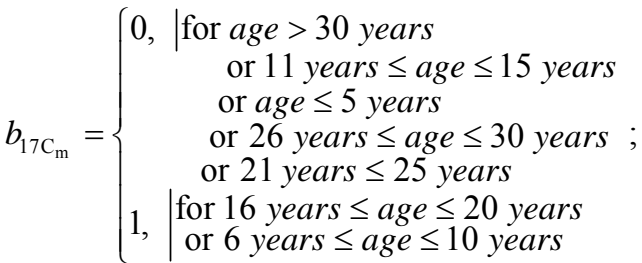

$b_{17 \mathrm{~B}_{\mathrm{m}}}=\left\{\begin{array}{l}0, \text { for age }>30 \text { years } \\ \text { or } 26 \text { years } \leq \text { age } \leq 30 \text { years } \\ \text { or } 6 \text { years } \leq \text { age } \leq 10 \text { years } \\ \text { or } 0<\text { age } \leq 5 \text { years. } \\ -0.55, \text { for } 21 \text { years } \leq \text { age } \leq 25 \text { years. } \\ -21.32, \text { for } 16 \leq \text { age } \leq 20 \text { years. } \\ -14.51, \text { for } 11 \text { years } \leq \text { age } \leq 15 \text { years. }\end{array}\right.$

\subsection{Discussion of Regression Models}

\subsubsection{Regression Model Validation}

Geita Gold Mines was selected as the case study in assessment of the generated regression models performance. Generated regression models (5) and (8) models were first validated by calculating the percentage difference between the predicted values and the actual values of the cash-cost and country-benefit for the case study Geita Gold Mines. The validation results obtained are shown in Table 3. The results show that the cash-cost and country-benefit models can predict cash-cost and country-benefit of Geita Gold Mines within an error of \pm $10 \%$ (except for the year 2002 and 2003 when the actual country benefits were much greater than the predicted, resulting to prediction error which is $>>10 \%$.

\subsubsection{Possibility of Cash-Cost Reduction}

The determinant country variables on (5) differ from one country to the other and for the Geita Gold Mines, envi- ronmental regulations $\left(X_{2}\right)$ and regulatory duplication and inconsistencies $\left(X_{3}\right)$, each varying from $0 \%$ to $90 \%$ are the only country variables which can be regulated to achieve the desired level of cash-cost in which the lowest cash-cost possible could be obtained from having the values of $X_{2}$ and $X_{3}$ set at $0 \%$ as it was in Argentina, Mexico, Chile, Australia and Canada in the year 2003 of the examined period from 2002 to 2008. The maximum cash cost could be obtained from having the values of $X_{2}$ and $X_{3}$ set at $90 \%$ as it was in USA in the year 2003 and Chile and Mexico in the year 2008 of the examined period. During the examined period, the values of $X_{2}$ and $X_{3}$ for the Geita Gold Mines varied from $4 \%$ to $27 \%$ and from $12 \%$ to $46 \%$ respectively. Variations of the actual, predicted, minimum and maximum cash costs of Geita Gold Mines during the examined period are shown on Figure 1, showing that the actual cash-cost could be reduced to the minimum value possible from having variables $X_{2}$ and $X_{3}$ set at their minimum possible value of $0 \%$.

As shown on Table 2, the annual cash-cost savings which could be achieved at Geita Gold Mines from having $X_{2}$ and $X_{3}$ set at their possible best values in the examined period which varies from 10.97 to 83.32 US\$/oz as illustrated on Figure 1.

\subsubsection{Possibility of Country-Benefit Increment}

The determinant country variables on (8) also differ from one country to the other and for the Geita Gold Mines, taxation regime deterrence of investment $\left(X_{4}\right)$ Uncertainty concerning native land claims deterrence of investment $\left(X_{5}\right)$ and infrastructural deterrence of invest$\operatorname{ment}\left(X_{7}\right)$, each varying from $0 \%$ to $95 \%$ are the only country variables which can be regulated to achieve the desired level of country-benefit in which the highest country-benefit possible could be obtained from having the value of $X_{4}$ set at $95 \%$ as it was in Zimbabwe and Venezuela in the year 2008, $X_{5}$ at $0 \%$ as it was in Russia, China, Brazil, Chile and Tanzania in the year 2003 and $X_{7}$ at $95 \%$ as it was in Kyrgyzstan in the year 2008 of the examined period from 2002 to 2008. The minimum country-benefit could be obtained from having the value of $X_{4}$ set at $0 \%$ as it was in Australia in the year 2003, $X_{5}$ at $95 \%$ as it was in Ecuador in the year 2008 and $X_{7}$ at $0 \%$ as it was in USA, Australia and Canada in the year 2003 of the examined period. During the examined period, the values of $X_{4},\left(X_{5}\right)$ and $X_{7}$ for the Geita Gold Mines varied from $20 \%$ to $38 \%$, from $0 \%$ to $34 \%$ and from $7 \%$ to $38 \%$ respectively. Variations of the actual, predicted, minimum and maximum country-benefits of Geita Gold Mines during the examined period are shown on Figure 2, showing that the actual country-benefit could be increased to the maximum 
Table 3. Results of validation of cash cost and country benefit regression models based on Geita Gold Mines data.

\begin{tabular}{ccccccc}
\hline \multirow{2}{*}{ Year } & \multicolumn{3}{c}{ Cash Costs US US\$oz } & \multicolumn{3}{c}{ Country Benefit US US\$/oz } \\
\cline { 2 - 7 } & Actual & Predicted & \% Difference & Actual & Predicted & \% Difference \\
\hline 2002 & 175.00 & 163.23 & -6.73 & 13.77 & 11.17 & -18.87 \\
2003 & 183.00 & 186.46 & 1.89 & 16.66 & 12.20 & -26.77 \\
2004 & 250.00 & 237.11 & -5.16 & 13.98 & 13.34 & -4.56 \\
2005 & 298.00 & 268.80 & -9.80 & 20.00 & 128.84 & -5.78 \\
2006 & 397.00 & 344.32 & -13.27 & 30.63 & 30.41 & -0.71 \\
2007 & 452.00 & 410.91 & -9.09 & 46.35 & 46.51 & -0.34 \\
2008 & 528.2 & 515.26 & -2.83 & 56.45 & 55.99 & -0.81 \\
\hline
\end{tabular}

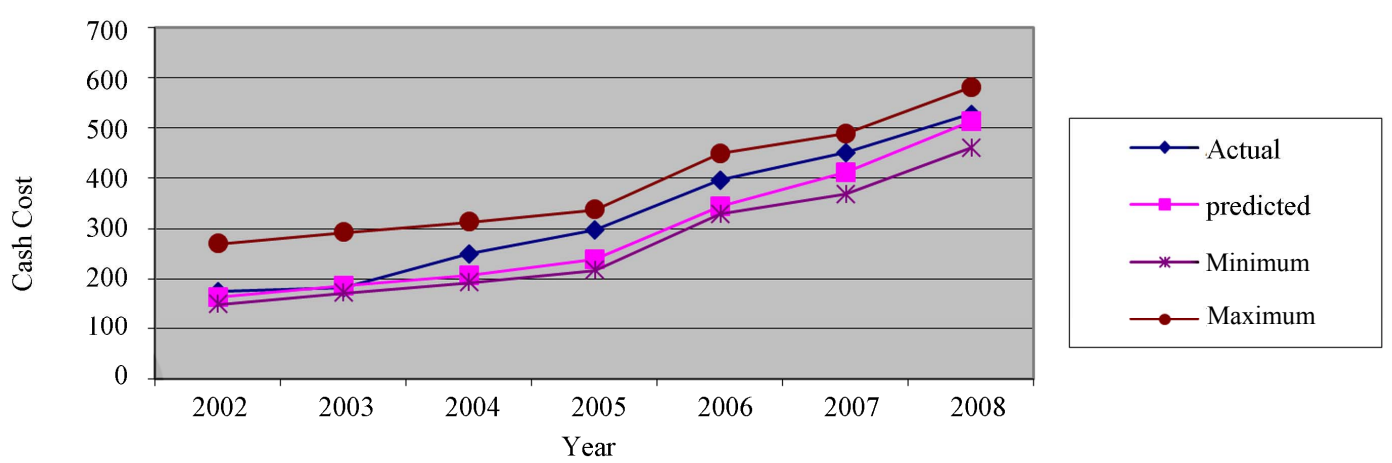

Figure 1. The graph of the actual, predicted, minimum and maximum cash cost of Geita Gold Mines from 2002 to 2008.

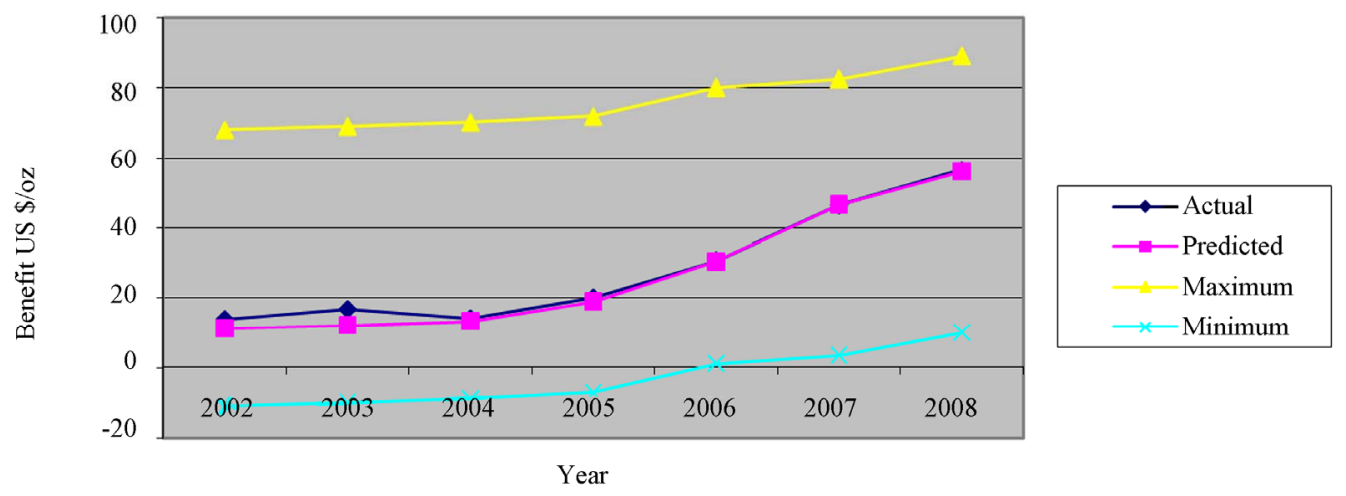

Figure 2. The graph of the actual, predicted, minimum and maximum country benefit of Geita Gold Mines from 2002 to 2008.

value possible from having variable $X_{4}$ set at the maximum possible value of $95 \%,\left(X_{5}\right)$ at the minimum possible value of $0 \%$ and $X_{7}$ at the maximum possible value of $95 \%$.

As shown on Table 4, the annual additional country-benefit which could be achieved at Geita Gold Mines from having $X_{4}, X_{5}$ and $X_{7}$ set at their possible best values in the examined period which varies from 32.59 to 56.32 US\$/oz as illustrated on Figure 2.

\subsubsection{Country Variations Effect on Mine Cash-Cost and Country-Benefit}

Cash-costs and country-benefits were calculated using the regression models developed in this study for the rock-mass and mine-design parameters of the Geita Gold Mines operating in country parameters of variable gold mining countries for the period from 2002 to 2008 and presented as illustrated on Figure 3 and Figure 4 respectively. From the figures, it could be observed that in terms of cash-cost and country-benefit, the Geita Gold Mines operating in the country parameters of Tanzania was $14^{\text {th }}$ and $8^{\text {th }}$ respectively relative to the cash-cost and country-benefit effects of having the mine operating in the country parameters of the other 18 countries examined in this study. The figures also show that Tanzania could achieve the minimum of the cash-costs and maximum of country-benefits achieved in some of the examined countries for the year 2008 shown on Table 5 from having its 
Table 4. Cash-cost savings and country-benefit gains achievable from having Geita Gold Mines operating at the best setting of its country parameters.

\begin{tabular}{ccccccc}
\hline Year & \multicolumn{3}{c}{ cash costs US US\$/oz } & \multicolumn{2}{c}{ country benefit US US\$/oz } \\
\cline { 2 - 7 } & actual & Minimum & potential cash-cost savings & maximum & actual & possible additional country-benefit \\
\hline 2002 & 175.00 & 148.79 & 26.21 & 68.13 & 13.77 & 54.36 \\
2003 & 183.00 & 172.03 & 10.97 & 69.16 & 16.66 & 52.50 \\
2004 & 250.00 & 192.68 & 57.33 & 70.30 & 13.98 & 56.32 \\
2005 & 298.00 & 217.30 & 80.70 & 71.95 & 20.00 & 51.95 \\
2006 & 397.00 & 329.37 & 67.63 & 80.19 & 30.63 & 49.56 \\
2007 & 452.00 & 368.68 & 83.32 & 82.62 & 46.35 & 36.27 \\
2008 & 528.20 & 461.89 & 66.31 & 89.04 & 56.45 & 32.59 \\
\hline
\end{tabular}

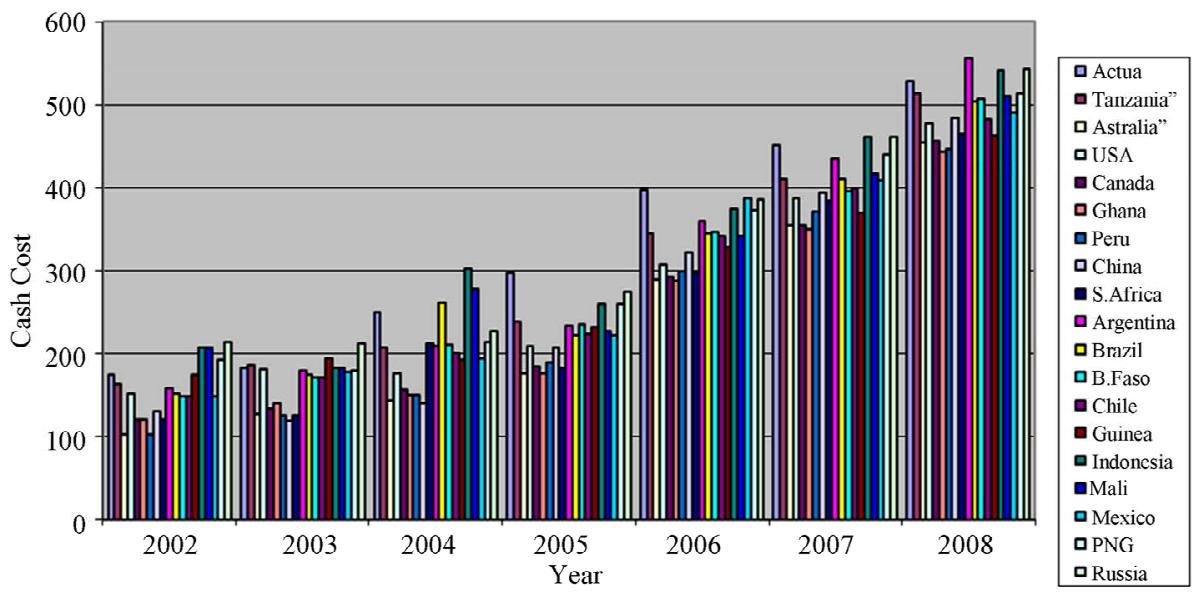

Figure 3. Comparative cash-cost variations of the Geita Gold Mines operating in different countries from 2002 to 2008.

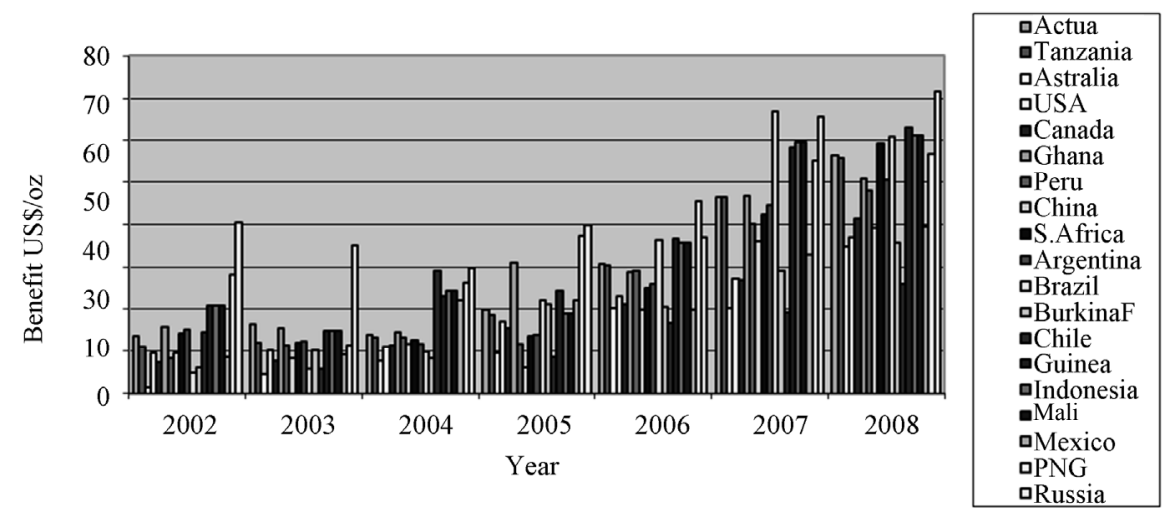

Figure 4. Comparative country-benefit variations of the Geita Gold Mines operating in different countries from $2002-2008$.

parameters of country set at their most rewarding values without compromising cash-cost and attractiveness of the mine for investment relative to the other countries examined in this study to become $5^{\text {th }}$ and $1^{\text {st }}$ instead of $14^{\text {th }}$ and $8^{\text {th }}$ respectively and enjoy a minimum cash cost
461.89 US\$ and a maximum country-benefit of 89.04 US\$ respectively.

Cash-cost savings and country-benefit gains achievable from having Geita Gold Mines operating at the best setting of its country parameters shown on Table 4 
Table 5. Cash-cost and country-benefit of Geita Gold Mines operating in different countries in 2008.

\begin{tabular}{|c|c|c|c|c|c|}
\hline country & $\begin{array}{c}\text { predicted cash cost } \\
\text { (US\$/oz) }\end{array}$ & ranking & country & $\begin{array}{c}\text { predicted country } \\
\text { benefit (US\$/oz) }\end{array}$ & ranking \\
\hline Ghana & 442.42 & 1 & Russia & 71.56 & 1 \\
\hline Peru & 446.44 & 2 & Indonesia & 63.20 & 2 \\
\hline Australia & 454.42 & 3 & Mali & 61.23 & 3 \\
\hline Canada & 455.51 & 4 & Burkina Faso & 60.90 & 4 \\
\hline Guinea & 461.89 & 5 & Brazil & 60.9 & 5 \\
\hline S. Africa & 464.82 & 6 & Argentina & 59.45 & 6 \\
\hline USA & 477.74 & 7 & China & 56.88 & 7 \\
\hline Chile & 483.00 & 8 & PNG & 56.64 & 8 \\
\hline China & 483.28 & 9 & Tanzania & 55.99 & 9 \\
\hline Mexico & 491.27 & 10 & Ghana & 50.88 & 10 \\
\hline Brazil & 503.11 & 11 & Peru & 48.10 & 11 \\
\hline Burkina Faso & 507.10 & 12 & Canada & 41.52 & 12 \\
\hline Mali & 509.47 & 13 & Mexico & 39.60 & 13 \\
\hline Tanzania & 513.26 & 14 & S. Africa & 39.20 & 14 \\
\hline PNG & 513.29 & 15 & USA & 37.15 & 15 \\
\hline Indonesia & 541.03 & 16 & Chile & 35.67 & 16 \\
\hline Russia & 543.45 & 17 & Australia & 34.72 & 17 \\
\hline Argentina & 555.41 & 18 & Guinea & 25.93 & 18 \\
\hline
\end{tabular}

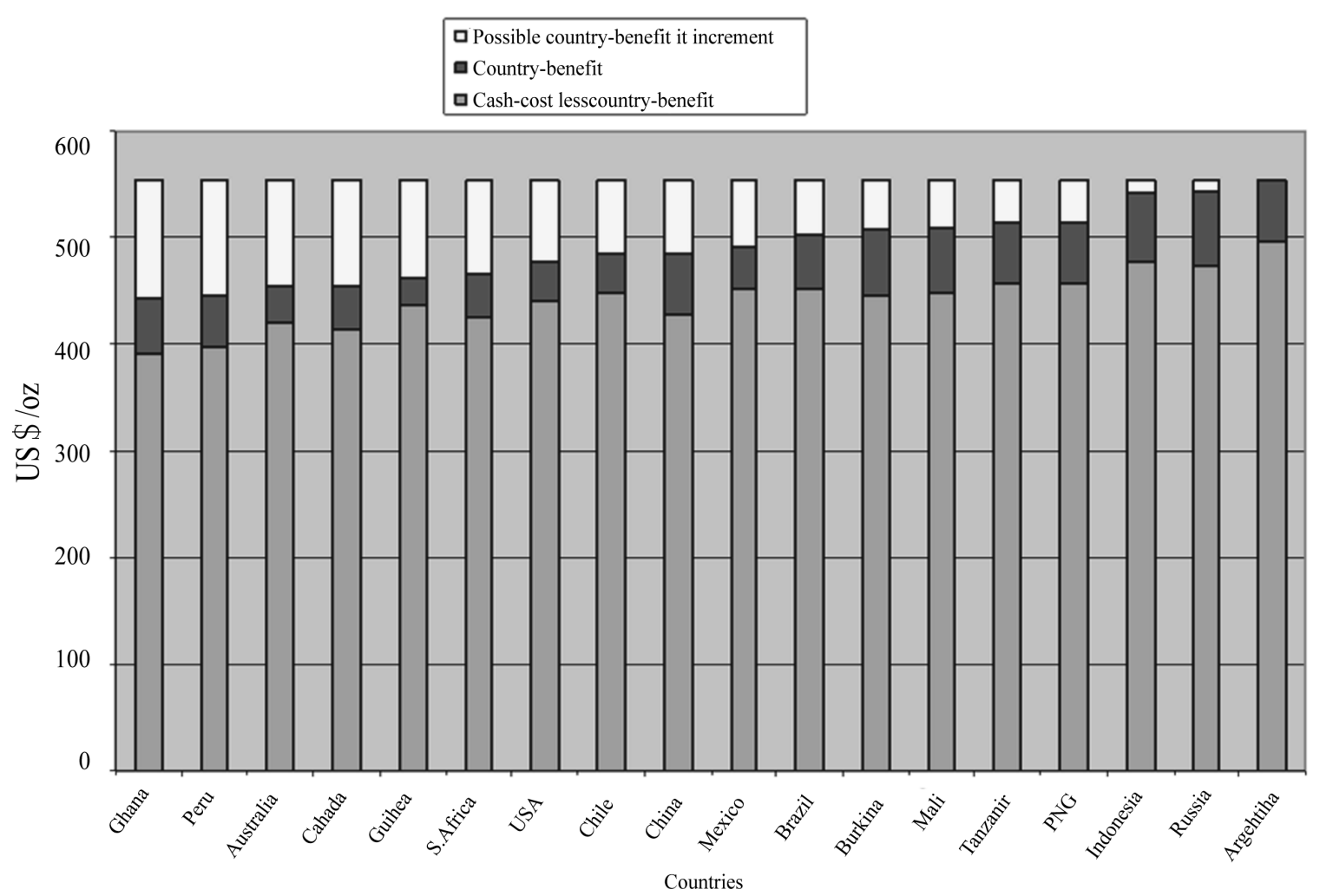

Figure 5. Cash-cost savings and country-benefit gains achievable from having Geita Gold Mine operating at the best setting of its country parameters.

are presented graphically on Figure 5. From this figure it could be observed that countries such as Ghana, Peru and Australia are registering lower cash-costs than countries such as Argentina and Russia and therefore could still regulate their country parameters in order to increase their country benefits. Conversely, in accordance to this figure, Argentina could regulate its country-parameters to sacrifice some of its country-benefit in order to become more attractive for investments.

\section{Conclusions}

Generated regression models summary presented on Table 2 constitutes the basis of discussion. 


\subsection{Cash-Cost Models}

$>$ Cash-cost fit on mine variables: Accounted for mine variables constitute $69.7 \%$ of the determinants variables of cash-cost. This means that the unaccounted for mine variables constitute $30.3 \%$ of the determinants variables of cash-cost.

$>$ Cash-cost fit on country variables: Accounted for country variables constitute $34.1 \%$ of the determinants variables of cash-cost. This means that the unaccounted for country variables constitute $65.9 \%$ of the determinants variables of cash-cost.

$>$ Cash-cost fit on mine and country variables: Accounted for mine and country variables constitute $71 \%$ of the determinants variables of cash-cost. This means that the unaccounted for mine and country variables constitute $29 \%$ of the determinants variables of cash-cost.

\subsection{Country-benefit models}

$>$ Country-benefit fit on mine variables: Accounted for mine variables constitute $50.6 \%$ of the determinants variables of country-benefit. This means that the unaccounted for mine variables constitute $49.4 \%$ of the determinants variables of country-benefit.

$>$ Country-benefit fit on country variables: Accounted for country variables constitute $27.7 \%$ of the determinants variables of country-benefit. This means that the unaccounted for country variables constitute $72.3 \%$ of the determinants variables of country-benefit.

$>$ Country-benefit fit on mine and country variables: Accounted for mine and country variables constitute $55 \%$ of the determinants variables of country-benefit. This means that the unaccounted for mine and country variables constitute $45 \%$ of the determinants variables of country-benefit.

The summary of regression models generated in this study and presented on Table 2 allows concluding that the parameters of rock-mass, mine-design and country variations considered in the regression analysis are not all which determine cash-cost and country-benefit.

Depending on the availability of data, the regression models generated in this study could be enhanced by adding into the parameters used in the regression analysis, the unaccounted for parameters such as the subcomponents of cash-costs instead of the total cash-costs used in this study, ore-hardness, ore-processability, type of mining method, method of mine transport and method of mine dewatering.
Also, Depending on the availability of data, the Regression models generated in this study could be enhanced further by replacing the parameters of Fraser Institute ranking used in the regression analysis with the actual parameters of country effect on cash-cost and country-benefit of the gold produced, including the actual costs in taxation and royalty, fuels and other supplies and services.

Nevertheless, the regression models generated in this study could be used to predict the cash-costs and country-benefits of gold mining opportunities in the justification of taxation regimes and selection of investment targets worldwide.

\section{References}

[1] J. Otto, J. Cordes and M. L. Bastarch, "Global Mining Comparative Study," 2nd Edition, Institute of Global Resources Policy and Management, Colorado School of Mines, Golden, 2000.

[2] F. McMahon and M.Cervantes, "Fraser Institute Annual Survey of Mining Companies 2008/2009," Fraser Institute, Vancouver, 2009.

[3] Raw Materials Group, "Raw Materials data metals and coal," Raw Materials Group, Solna, 2010.

[4] World Gold Council, Internet Available: http://www.gold. org

[5] T. Baunsgaard, "A Primer on Mineral Taxation," International Monetary Fund, 2001.

[6] J. Otto, "Mining Royalties: A Global Study of Their Impact on Investors, Government, and Civil Society," World Bank Publications, 2006.

[7] F. Cawood, "An Independent Analysis of the 2006 Draft Royalty Bill for the South African Mineral and Petroleum Sectors," Journal of the South African Institute of Mining and Metallurgy, Vol. 107, No. 8, 2007, pp. 493-504.

[8] T. Reeve, M. Turner and C. Firman, "Gold Mine Cost Report-Q1 2010," VM Group Research for Fortis Bank Nederland, the Hedge Survey, June 2010.

[9] L. A. Readdy, D. S. Bolin and G. A. Mathieson, "Ore Resereve Calculation," In: R. E. Gertsch and R. L. Bullock, Ed., Techniques in Underground Mining: Selections from Underground Mining Methods Handbook, Society for Mining, Metallurgy, and Exploration, Inc., Littleton, 1998, pp. 3-43.

[10] H. Hamrin, "Choosing an Underground Mining Method," In: R. E. Gertsch and R. L. Bullock, Ed., Techniques in Underground Mining: Selections from Underground Mining Methods Handbook, Society for Mining, Metallurgy, and Exploration, Inc., Littleton, 1998, pp. 45-85.

[11] R. L. Bullock, "General Mine Planning," In: R. E. Gertsch and R. L. Bullock, Ed., Techniques in Underground Mining: Selections from Underground Min- ing Methods Handbook, Society for Mining, Metallurgy, and Exploration, Inc., Littleton, 1998, pp. 87-126. 
[12] W. Hustrulid and M. Kuchta, "Open Pit Mine: Planning \& Design," 2nd edition, Taylor \& Francis, London, 2006.

[13] H. Hartman, "SME Mining Engineering Handbook," Society for Mining Metallurgy, 1992.

[14] D. E. Nicholas and J. M. Marek, "The Feasibility StudySelection of a Mining Method Intergrating Rock Mechanics and Mine Planning," Proceedings of Rapid Excavation and Tunneling Conference, Vol. 2, 1981, pp. 1018- 1031.

[15] R. K. Warner and N. H. Conn, "Selection of a Mining System," New York Meeting, New York, February 1933, pp. 11-24.
[16] D. O’Neill, "Mining investment in Africa: An Australian Perspective," United Nations, Vol. 17, 1993, pp. 262272.

[17] C. Johnson. "Ranking Countries for Minerals Exploration," John Wiley \& Sons, 1990.

[18] J. Otto, "Criteria and Methodology for Assessing Mineral Investment Conditions," 1992.

[19] Behre Dolbear Group Inc., "2010 Ranking of Country for Mining Investment: Where Not to Invest," 2010. http:// www.dolbear.com/publications/CountryRanking.pdf

\section{Appendix 1: Sources of Data}

\begin{tabular}{|c|c|}
\hline Variables & Sources and links \\
\hline $\begin{array}{l}\text { Country variables } \\
\text { Gold price } \\
\text { Cash cost, resource size, resource grade, quantity of resource gold, reserve size, } \\
\text { reserve grade, quantity of reserve gold, run-of mine size, run-of-mine grade, quan- } \\
\text { tity of run-of-mine gold, presence of by-product/s, type of mine, age of mine, rate of } \\
\text { gold production } \\
\text { Depth of mine (m), type of ore body, angle of dip (degree), strike length (m), and } \\
\text { thickness (m), Production taxes and royalties }\end{array}$ & $\begin{array}{l}\text { http://www.fraserinstitute.org } \\
\text { http://www.research.gold.org/price/annual } \\
\text { http://www.rmg.se } \\
\text { http://www.mining-technology.com/projects, } \\
\text { http://www.anglogold.com, http://www.ashantigold.com } \\
\text { http://www.kinross.com } \\
\text { http://www.goldfieldsco.za } \\
\text { http://www.newmont.com } \\
\text { http://www.harmonygoldcorp.com } \\
\text { http://www.goldcorp.com } \\
\text { http://www.dominion.com } \\
\text { http://www.buenavenrura.com } \\
\text { http://www.eldoradogold.com } \\
\text { http://www.sinogold-pty-ltd.com } \\
\text { http://www.sme.org }\end{array}$ \\
\hline
\end{tabular}




\section{Appendix 2: Summary of the main results of regression models}

\begin{tabular}{|c|c|c|}
\hline & Cash-cost model (5) & Country-benefit model ( 8) \\
\hline Number of observations & 675 & 272 \\
\hline Dependent variables & Cash-cost per ounce & Country-benefit per ounce \\
\hline Independent variables & estimated coefficient & estimated coefficient \\
\hline Constant & $152.41 * * *(8.412)$ & $34.41 * * *(4.270)$ \\
\hline Annual average gold price & $0.493 * * *(22.503)$ & $0.028 * *(2.916)$ \\
\hline The rate of gold production & $-59.55 * * *(-6.372)$ & $-11.54 * * *(-3.299)$ \\
\hline The run-of-mine grade & $-59.66 * * *(-4.812)$ & $-8.58(-1.731)$ \\
\hline Dummy UG & $21.04(1.546)$ & $-10.37(-1.757)$ \\
\hline Dummy for OP\&UG & $34.71 * *(3.026)$ & $-5.53(-1.236)$ \\
\hline Dummy for with by-product & $-26.20 * * *(-3.643)$ & $-5.836(-1.937)$ \\
\hline Dummy for tabular or reef & $12.57(1.000)$ & $9.291(1.869)$ \\
\hline Dummy for massive & $-20.58(-1.879)$ & $12.36 * *(3.161)$ \\
\hline Dummy for complex & $54.27 *(2.287)$ & $4.44(0.348)$ \\
\hline Dummy for several veins & $-13.551(-1.208)$ & $-0.46(-0.085)$ \\
\hline Dummy for $120^{\circ}<\operatorname{dip} \leq 40^{\circ}$ & $28.15(1.867)$ & $-8.50(-1.365)$ \\
\hline Dummy for $40^{\circ}<\operatorname{dip} \leq 60^{\circ}$ & $5.61(0.588)$ & $-9.64 *(-2.146)$ \\
\hline Dummy for $80^{\circ}<\operatorname{dip} \leq 90^{\circ}$ & $34.40(1.275)$ & $-8.08(-1.202)$ \\
\hline Dummy for complex dip angle & $8.33(0.643)$ & $8.36(1.678)$ \\
\hline Dummy for $500<$ Strike $\leq 1000 \mathrm{~m}$ & $4.15(0.418)$ & $-3.39(-0.581)$ \\
\hline Dummy for $1000<$ Strike $\leq 1500 \mathrm{~m}$ & $-34.83 *(-2.428)$ & $-10.69(-1.619)$ \\
\hline Dummy for $1500<$ Strike $\leq 2000 \mathrm{~m}$ & $-8.45(-0.697)$ & $18.84 * * *(3.371)$ \\
\hline Dummy for Strike $>2000 \mathrm{~m}$ & $13.64(1.198)$ & $-5.17(-1.269)$ \\
\hline Dummy for $2.0<$ thickness $\leq 5.0 \mathrm{~m}$ & $-35.33 *(2.428)$ & $18.85 * *(2.591)$ \\
\hline Dummy for complex thickness & $13.62(1.092)$ & $-21.14 * * *-3.779$ \\
\hline Dummy for $5.0<$ thickness $\leq 10.0 \mathrm{~m}$ & $-43.12(-3.968)$ & $2.04(0.432)$ \\
\hline Dummy for thickness $>10.0 \mathrm{~m}$ & $-33.67 * *(-3.013)$ & $-4.33(-1.027)$ \\
\hline Dummy for hard rock & $-32.82 * * *(-4.08)$ & $-1.43(-0.468)$ \\
\hline Dummy for very hard rock & $-70.42 * * *(-4.661)$ & $2.01(0.401)$ \\
\hline Dummy for $300<$ depth $\leq 500 \mathrm{~m}$ & $-19.45(-1.788)$ & $2.26(0.642)$ \\
\hline Dummy for $500<$ depth $\leq 1000 \mathrm{~m}$ & $-14.83(-1.009)$ & $14.86 *(2.539)$ \\
\hline Dummy for $1000<$ depth $\leq 1500 \mathrm{~m}$ & $28.48 *(1.999)$ & $-2.41(-0.393)$ \\
\hline Dummy for $1500<$ depth $\leq 2000 \mathrm{~m}$ & $21.33(1.194)$ & $0.043(0.005)$ \\
\hline Dummy for $2000<$ depth $\leq 3000 \mathrm{~m}$ & $29.04(1.404)$ & $0.56(0.066)$ \\
\hline Dummy for $26 \leq$ age $\leq 30$ years & $24.39(1.592)$ & $-0.56(-0.078)$ \\
\hline Dummy for $21 \leq$ age $\leq 25$ years & $18.87(1.564)$ & $-10.55 *(-2.294)$ \\
\hline Dummy for $16 \leq$ age $\leq 20$ years & $37.00 * *(2.697)$ & $-21.32 * * *(-4.129)$ \\
\hline Dummy for $11 \leq$ age $\leq 15$ years & $-10.58(-0.936)$ & $-14.51 * * *(-3.474)$ \\
\hline Dummy for $6 \leq$ age $\leq 10$ years & $-37.81 *(-2.422)$ & $-1.21(-0.227)$ \\
\hline Dummy for age $\leq 5$ years & $-10.76(-0.616)$ & $-10.59(-1.727)$ \\
\hline Regulatory duplications and inconsistencies & $+79.91 *(+1.985)$ & - \\
\hline Environmental regulations & $54.14 * * *(3.227)$ & - \\
\hline Taxation regime & $14.08(0.45)$ & $25.09 * *(2.747)$ \\
\hline Labor regulations & $59.77(1.428)$ & $-24.02(-1.651)$ \\
\hline Political stability & $-39.09(-1.323)$ & - \\
\hline Infrastructure & - & $39.28 * *(3.161)$ \\
\hline Socioeconomic agreement & - & $-23.52(-1.644)$ \\
\hline Uncertainty concerning native land & - & $-16.28 *(-2.144)$ \\
\hline
\end{tabular}

Sources: Author's calculation; Note $\mathrm{R}^{2}=0.705$ for model 5 and 0.55 for model 8 ; t-values are presented in parenthesis below the regression coefficients. Coefficients marked $* * * p<0.001, * * \mathrm{p}<0.01 * \mathrm{p}<0.05$. 